\title{
軟弱路床への荷重低減を目的とした 袋詰めエアミルクの適用例
}

\author{
辻慎一朗 $1 \cdot$ 山田幹雄 ${ }^{2} \cdot$ 吉田眞輝 $3 \cdot$ 南和弘 $4 \cdot$ 安永豊 5
}

\begin{abstract}
道路舗装は，供用後の交通荷重により規定の管理値まて性能力低下したとき，補修や再建設を行うことにな る.特に, 道路の路床力軟弱な場合, 路床の沈下に伴って発生する路面のクラックや段差に対する定期的な補 修が必要になる . 著者らは, 新しい舖装構成材料として , ジオテキスタイル製の袋材に軽量のエアミルクを注 入した「袋詰めエアミルク」を開発した . 光して, 軟弱な路床への荷重の低減による道路の補修周期の延長を 目的として，路床上に袋詰めエアミルクを敷設し，光の上に加熱アスファルト混合物を舗設する実施工を行っ た . 本論文では袋詰めエアミルクの特性を述べるほか, 路盤に袋詰めエアミルクを用いた舗装断面の設計およ び施工概要を報告する．
\end{abstract}

キーワード：舗装, 性能設計, 袋詰めエアミルク , 荷重低減

1 . はじめに

道路構造令の改正により，舗装材料の種類による仕樣 規定から , 材料物性などの性能規定化か進められている. アスファルト舗装は, 一般に表層, 基層, 路盤と厚さ約 $1 \mathrm{~m}$ の路床で構成されるが, 道路供用後の交通荷重など により規定のレベルまて性能力低下した場合は，舗装を 補修または再建設（舗装の打換え）を行うことになる。 特に, 路床力軟弱な場合, 供用後の路床の沈下に伴って 発生する路面のクラックや段差に対する定期的な補修が 必要となる。

舗装の構造設計では, 舗装の設計期間（疲学破壊に よりひひ割れか甡じるまで期間) にわたって疲労破壊 抵抗性を確保するように, 舗装の構成と厚さ, 使用材料 を決定することとしている1). 舗装の構造設計おいて道 路のライフサイクルを考慮する必要があり, 設計期間に わたって道路の性能力確保できるよう, 適切な使用材料 を用いることか望ましい，乥こで，著者らは新たな舗装 構成材料として , ジオテキスタイル製の袋材の中にエア ミルクを注入した「袋詰めエアミルク」を開発した .セ メント, 水, 気泡からなるエアミルクは軽量であるため, 軟弱な路床上の舗装に有効である。既往の研究において， 袋詰めエアミルクは, 厚さか約3倍の構筑路床 (路床の 支持力が小さい場合に, 路床の一部または全部を改良し た部分）と同等の岡性と支持力特性を持つことを確忍し ている2，3，4)，5)．引き続いて，著者らは現道の舗装
工事に袋詰めエアミルクを路盤材料として適用する設計 と施工を行った . 実施工に先立ち, 初めに袋詰め工アミ ルクの曲け棓式験を行い, エアミルク単体と比べると袋材 を併用することで曲け強度が大きく向上することを確認 した . 次に, 舗装の理論的設計方法に基ついて断面を決 定するにあたり，袋詰めエアミルクの弾性係数をレジリ エントモデュラス試験 ${ }^{6)}$ から求めた . 袋詰めエアミルク の施工には, エアミルクを製造 , 圧送する小型のプラン 卜を用い, 道路延長 $100 \mathrm{~m} の$ 施工を約1ヶ月間 (袋詰め工 アミルクの養生と舗装工事も含む)て終えた . 本論文で は, 袋詰めエアミルクの特性, 多層弾性理論に基づく袋 詰めエアミルクを利用した舗装の設計と有限要素法によ る沈下量の算定, 施工概要を述べる.

\section{2 . 袋詰めエアミルクの特性}

施工に用いた袋詰めエアミルクの形状 , 寸法を図-1 に示す . 袋材は, 上下面は布製型枠 (引張強度 : 1910 $\mathrm{N} / 3 \mathrm{~cm}$ ) ，側面はポリエステル製の織布（引張強度 : $3040 \mathrm{~N} / \mathrm{cm})$ ，上下面を連結するポリプロピレン製のつ なぎ材て構成される.エアミルクの配合を表-1に示す． ここで, エアミルクの単位体積重量 $\left(6.3 \mathrm{kN} / \mathrm{m}^{3}\right)$ はコン クリートの $1 / 3$ 程度である.

小型の供試体 (長さ $600 \mathrm{~mm}$, 幅 $150 \mathrm{~mm}$, 厚さ $100 \mathrm{~mm}$ ないし 200mm) を用いて行った曲げ試験の状況を写真-

1正会員, 岐阜大学工学部, 社会基盤工学科, 助教 (广501-1193 岐阜県岐阜市柳戶1-1)

2正会員, 福井工業高等専門学校, 環境都市工学科, 教授 (T916-8507 福井県鯖江市下司町)

3正会員, 前田工䋊株式会社, 開発製造本部, 技術部 (广919-0422 福井県坂井市春江町沖布目38-3)

非会員, 前田工䋊株式会社, 開発製造本部, 技術部 (广919-0422 福井県坂井市春江町沖布目38-3)

5非会員, 前田工䋊株式会社, 開発製造本部、開発部 (广⿳919-0422 福井県坂井市春江町沖布目38-3) 


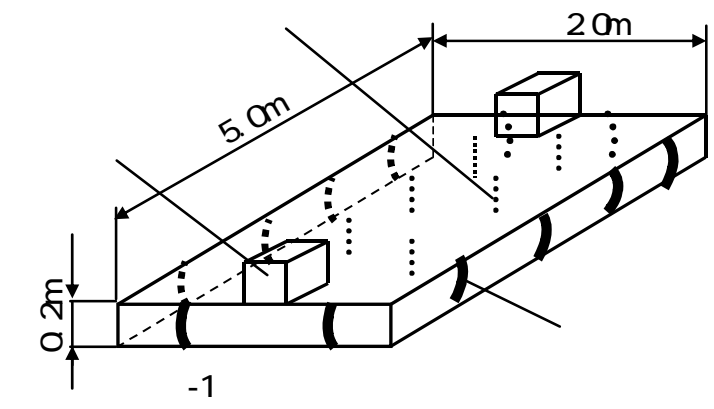

表-1 エアミルクの配合

\begin{tabular}{|l|c|}
\hline 压縮強度 $\left(\mathrm{kN} / \mathrm{m}^{2}\right)$ & 1000.0 \\
\hline 空気量 $(\%)$ & 59.5 \\
\hline 水セメント比 $(\%)$ & 820 \\
\hline セメント $\left(\mathrm{kg} / \mathrm{m}^{3}\right)$ & 353.0 \\
\hline 起泡斉 $\left(\mathrm{kg} / \mathrm{m}^{3}\right)$ & 103 \\
\hline 希釈水 $\left(\mathrm{kg} / \mathrm{m}^{3}\right)$ & 23.69 \\
\hline 混練水 $\left(\mathrm{kg} / \mathrm{m}^{3}\right)$ & 264.0 \\
\hline 湿潤密度 $\left(\mathrm{g} / \mathrm{cm}^{3}\right)$ & 0.64 \\
\hline 単位体積重量 $\left(\mathrm{kN} / \mathrm{m}^{3}\right)$ & 6.3 \\
\hline
\end{tabular}

1 に示す.曲け試験は中央点載荷装置を用いて行い, 支 間長を $450 \mathrm{~mm}$ とした .

試験結果の一例として厚さ $100 \mathrm{~mm}$ ，材齢 28 日の袋詰 めエアミルクおよびエアミルク単体の供試体における荷 重 - 変位の関係を図-2 に示す.エアミルク単体では , 供試体の中央付近にひひ割れが進展した直後に破壊した . 一方, 袋詰めエアミルクは, 載荷初期の段階て袋材のた るみと思われる変形か苼じたが, エアミルクの袋材への 付着と袋材の引張抵抗によって破壊に至るまでの変位が 大きくなった . 袋材の引張抵抗は載荷初期ではなく，供 試体の変形がある程度進行してから発揮されるようであ る.曲げ試験において, 袋内のエアミルクのひひ割れの 進展状況などは確認できなかったが, 袋材の引張抵抗に よりエアミルク単体に比べて鞀性が向上し, 変形への追 従性か高くなるといえる。

\section{3 . 軟弱地盤上の舗装工事への適用}

\section{（1）施工現場の概要}

施工は, 福岡県鞍手郡内の2車線, 幅員 $6.4 \mathrm{~m}$, 交通量 区分 $\mathrm{N}_{5}$ の県道で行った。補修前の埔装構成は, 路面から 厚さ $10 \mathrm{~cm} の$ 表 ・基層, 厚さ $15 \mathrm{~cm}$ の上層路盤（粒度調整 砕石) , 厚さ $15 \mathrm{~cm}$ の下層路盤 (再生クラッシャラン) であつた . 路床は軟らかい高有機質土の堆積層であり， この層の圧縮沈下に起因する平坦性の低下やひひ割れ率 の増大を短期間にきたしていた . 特に , カルバート埋設 箇所の進行方向前後には段差力泩じやすく，これまでに も施工基面高さを上げるためのオーバーレイか涉繁に施 され，また，構造的対策として舗装の打換えを行った経 緯もある . 弚こで, 軟弱な路床への荷重の負担を低減さ せ , 構造物付近における道路の補修周期の延長を目的と して, 軽量の袋詰めエアミルクを単独で用いた路盤を築

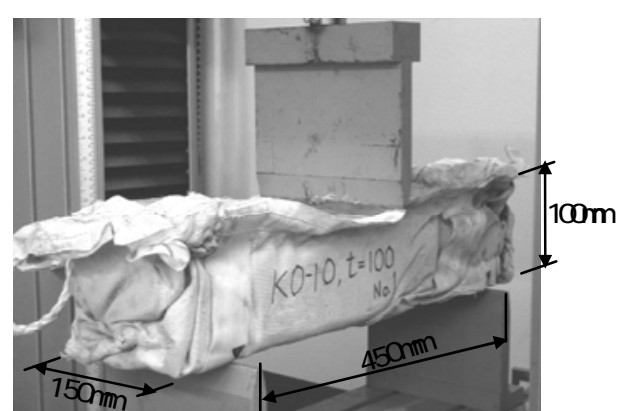

写真-1 袋詰めエアミルク (厚さ $100 \mathrm{~mm}$ ) に対する曲げ試験

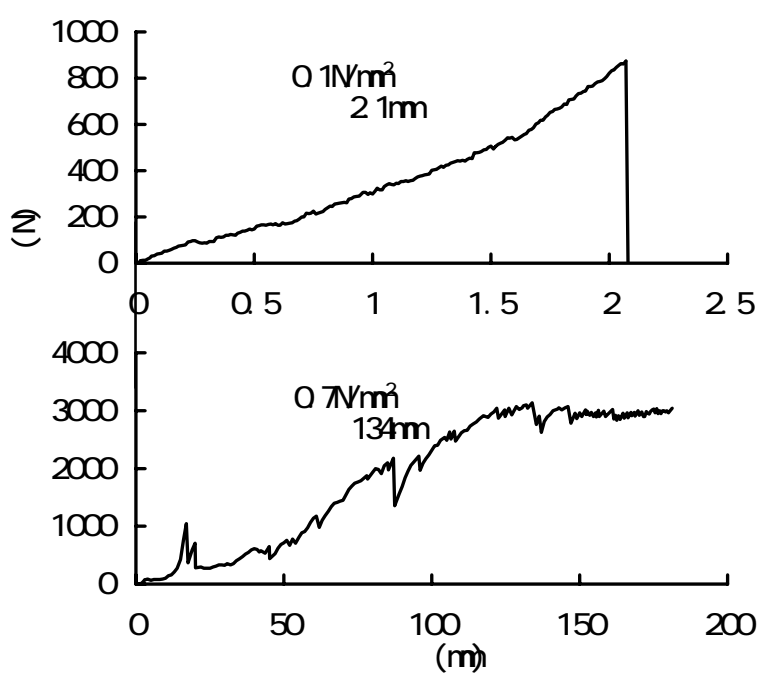

图 2 曲け試験の結果

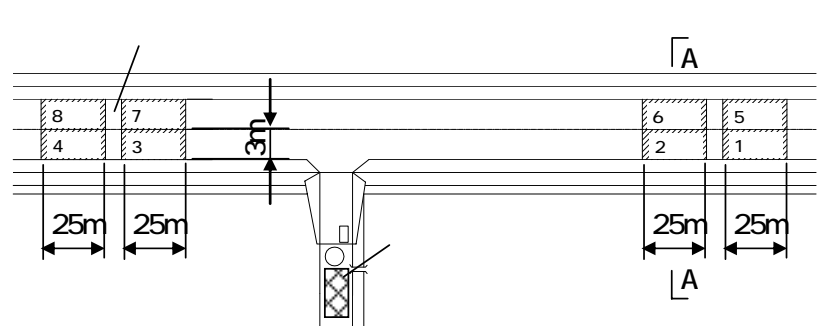

図 3 現場の平面図

表- 2 舗装の設計条件

\begin{tabular}{|l|c|}
\hline 舗装の設計期間 (年) & 10 \\
\hline 交通量区分 & $\mathrm{N}_{5}$ \\
\hline 舗装計画交通量 (台/日・方向) & 250 以上 1,000 未澫 \\
\hline 疲学破壊輪数 (回) & $1,000,000$ \\
\hline 信頼宽 (\%) & 90 \\
\hline
\end{tabular}

造することにした . 図-3に示すように , 1工区あたりの 袋詰めエアミルクの適用区間は, 幅は3.0m, 長さはカル

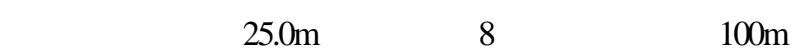
で補修を行った 。

\section{（2）袋詰めエアミルクを用いた舗装断面の設計}

多層戦性理論に基づく理論的設計法により, 袋詰め工 アミルクを用いた舗装断面を決定した . 具体的には, 舗 装構造解析プログラム $\mathrm{GAMES}^{7}$ を用い, アスファルト 混合物層およひ路床の破壊回数を信頼度に応じた係数で 割つた值力波労破壊輪数以上となる層厚を求めた. 設計 条件を表-2に示す.設計において, アスファルト混合物 と路床の弾性係数は規格值 ${ }^{1)}$ を用いた . 袋詰めエアミル 


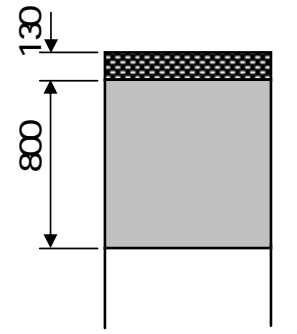

(a) 袋詰めエアミルク を用いた舗装

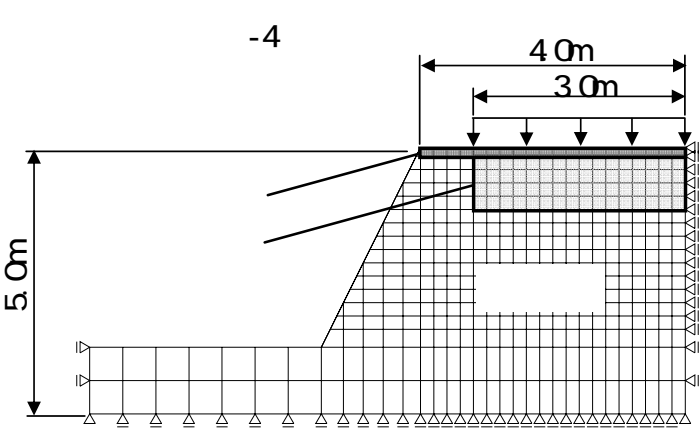

図-5 有限要素分割図

クの弾性係数は, 材齢28日のエアミルクに対するレジリ エントモデュラス試験6) より決定した值である $M_{r}=$ 600MPaを用いた .

理論的設計法で決定した袋詰めエアミルクを用いた 舗装断面を図-4(a)に示す．表-2の設計条件では，袋詰 めエアミルクの層厚は400mmて性能規定を満足した .し かし, 路盤の軽量化による路床の負担軽減を図るため, 舗装構成は軟弱な路床上に厚さ200mmの袋詰めエアミル

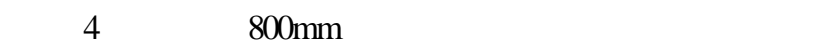
$130 \mathrm{~mm}$ 埔設することとした . 図-4(b) には，通常の舗装 に用いる材料 (粒度調整砕石, クラッシャラン) で, 表-2の設計条件を満足する舗装断面も併せて示した . 袋 詰めエアミルクを路盤材料として用いる効果を検証する ため, 図一4の舗装断面に対する有限要素解析を行った . 图-3のA-A'断面における有限要素分割図を図-5に示す。 舗装と路床は平面ひずみ要素で表す．解析に用いる物性 定数を表-3に示す.ここで, $\gamma$ : 単位体積重量, $E$ ： 弾性係数, $v$ : ポアソン比である.

地盤に対する詳細な土質調査が行われていなかった ため, 舗装構造解析プログラムGAMES ${ }^{7}$ による設計と 同樣に，舗装と路床は線形弾性体と仮定する．ここで， アスファルト混合物と路床の弾性係数は規格值 ${ }^{1)}$ を, 袋 詰めエアミルクの弾性係数は $M_{r}$ 值を用いる. 荷重とし て，路盤の自重と交通荷重 $10 \mathrm{kN} / \mathrm{m}^{2}$ (等分布荷重) を考 慮する. 路面の沈下量の計算結果を图一に二示す . 歩道部 分は通常の路盤構成であるため, 通常の路盤材料と袋詰 めエアミルクとの岡性と単位体積重量の大きさの違いに より，袋詰めエアミルクを用いた舗装では，道路中心か ら3m付近で不連続な変形か泩じていると考えられる. 舗装完成時, 交通荷重載荷時ともに, 袋詰めエアミルク を用いた舗装は通常舗装に比へて沈下量が秋さく, 軟弱 な路床の沈下に対する道路の補修周期を延長できる可能 性がある.ただし，路床の構成モデルや物性定数につい ては , 今後さらに検討する必要がある .
表-3 有限要素解析に用いる物性定数

\begin{tabular}{|l|r|r|r|}
\hline & $\mathrm{Y}\left(\mathrm{kN} / \mathrm{m}^{3}\right)$ & $\mathrm{E}\left(\mathrm{M} N / \mathrm{m}^{2}\right)$ & \multicolumn{1}{c|}{$\mathrm{v}$} \\
\hline アスファルト & 23.0 & 1900.0 & 0.35 \\
\hline 袋詰めエアミルク & 6.3 & 600.0 & 0.35 \\
\hline 粒度調整砕石 & 20.0 & 300.0 & 0.35 \\
\hline クラッシャラン & 20.0 & 200.0 & 0.35 \\
\hline 路床 & 19.0 & 40.0 & 0.40 \\
\hline
\end{tabular}

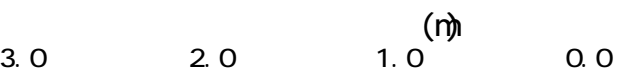

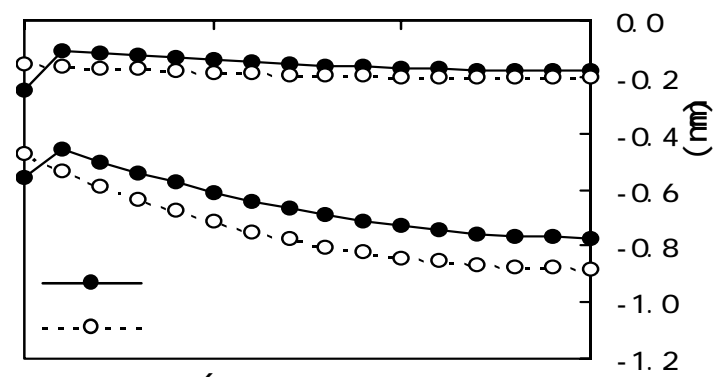

図 6 路面の沈下量の比較

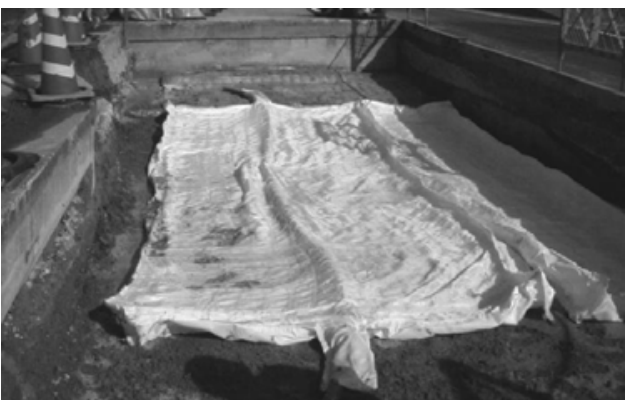

写真- 2 袋材の設置とエアミルクの注入

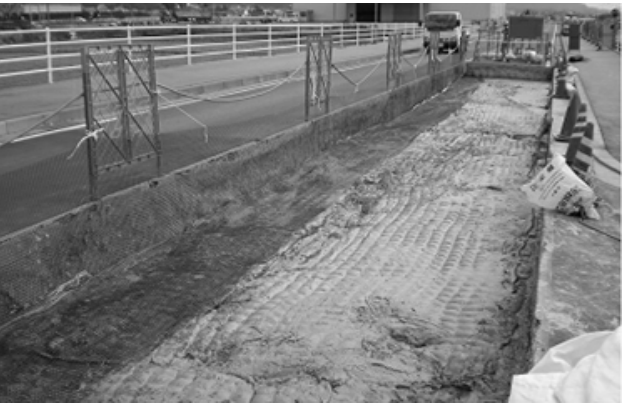

写真 3 継目の連結と段差防止シートの敷設

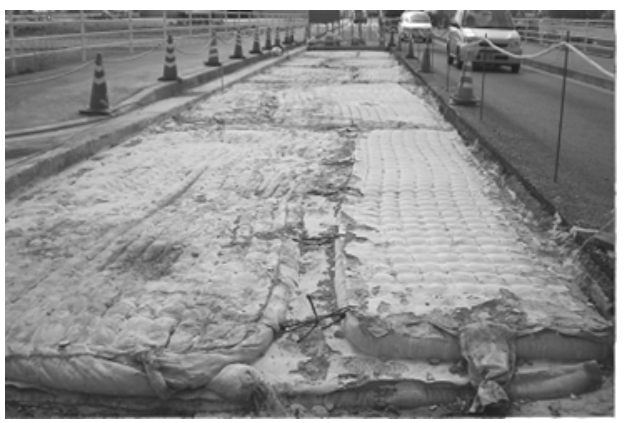

写真-4 袋詰めエアミルクの施工完了

\section{(3) 施工の概要}

セメント，水，気泡剂を混合してエアミルクを製造後， ポンプで圧送する可搬式の小型プラント ${ }^{8)}$ を図-3 中に 示す位置に設置して , エアミルクを注入した . 施工期間 が 2007 年 2 月中旬から 3 月末までと短かったので, 早 強セメントを使用し, エアミルクの養生期間の短縮を図 


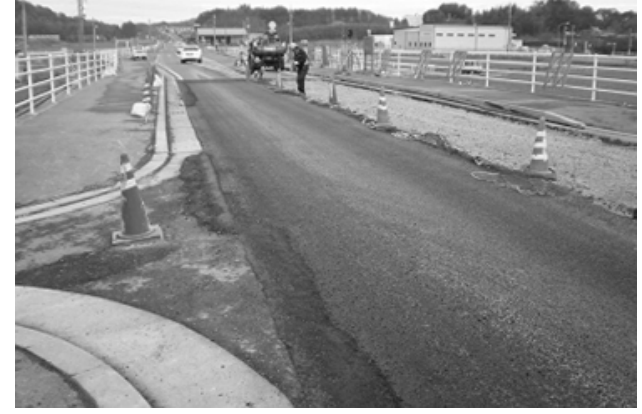

写真 5 表・基層の舗設完了

つた . 施工は片側車線ずつ行った .

施工手順を以下に示す .1) 路面を掘削後, 袋材を設 置し，エアミルクを注入する (写真- 2) . 注入後は 5 日 間養生する．2) 隣接する袋詰めエアミルクの継目をポ リプロピレン製のロープで連結する．3）上り車線と下 り車線との間に段差か栍じることを防ぐためにポリエス テル製のジオテキスタイル (引張強度 : 39.2kN/m) を敷 設する (写真-3) ，4）所定の厚さ分の袋詰めエアミル クを重ねる (写真-4) .5) アスファルト混合物を舗設 する (写真-5) . 施工後約 6 ケ月力経過した時点て路面 の状況を調査したが, 路面にひひ割れは認められず，ま た , 施工基面の沈下も確忍されなかった .

\section{4 . 結論}

本論文では, 交通荷重の軟弱な路床への作用荷重の低 減を目的として , ジオテキスタイル製の袋材の中にエア ミルクを注入した袋詰めエアミルクの路盤材料としての 適用例を示した . 本論文て得られた結論を以下に示す． 1) 袋詰めエアミルクに対する曲げ試験の結果, エアミ ルク単体に比へて曲け強度と破壊に至るまでの変位が大 きくなり，変形への追従性が高いことを確忍した。

2) 舗装の理論的設計法に基づいて袋詰めエアミルクを 用いた舗装断面を決定した . 有限要素法により，袋詰め エアミルクを用いた舗装は通常舗装に比へて道路供用後 の沈下量が小さく, 軟弱な路床の沈下に対する道路の補 修周期を延長できる可能性があることを確認した .
3）施工後の路面のひひ割れや段差は発生しておらず， 袋詰めエアミルクは路盤材料として十分な性能がある .

\section{5 .おわりに}

今後は , 袋詰めエアミルクを路盤に適用した舗装の性 能を確認するために，長期的な繰返し荷重の作用による 路面変状の有無を目視により継続して調べるほか， FWDで計測した路面のたわみ量を逆解析して袋詰め工 アミルクや路床の弾性係数を求める予定である . 補修工 事の立案，実施にあたりこ協力をいただいた，NPO法人 まちづくりネットワーク福岡の吉永政晴氏に感謝の意を 表します．

\section{参考文献}

1) 社団法人日本道路協会: 舗装設計便覧, 2006

2）山田幹雄, 辻慎一朗, 佐野博昭, 田辺和康: 袋詰めエアミルク の性能と道路路盤材料としての適用性, 材料, 2008 (掲載決 定).

3）山田幹雄, 辰野智規, 过慎一朗, 佐野博昭, 田辺和康, 坪川茂。藤 田智明 : 二層構成路床における支持力特性と強度特性との 関係について,第7回地盤改良シンポジウム論文集,pp.107-112, 2006.

4) 山田幹雄, 横田善弘, 三田村文寛, 佐野博昭, 田辺和康, 松田つ かさ : 袋詰め固化物の舗装構成材料としての有用性に関す る基礎研究, 第7回地盤改良シンポジウム論文集, pp.113-116, 2006.

5) 辻慎一朗, 山田幹雄, 吉田眞輝, 横田善弘 : ジオテキスタイル を用いた舗装の岡性評価, ジオシンセティックス論文集, 第 21巻,pp.11-16,2006.

6) 社団法人 日本道路協会 : 舖装試験法便覧別冊（暫定試験方 法) ,1996.

7）社団法人 土木学会 : 多層弾性理論による舗装構造解析入門, 2005.

8) 横田善弓。斎藤祐司, 南和弘:繊維を用いた軽量補強盛土につ いて,ジオシンセティックス論文集,第20巻,pp.137-140,2005.

\title{
APPLICATION OF PACKED-FOAMED CEMENT MILK TO CURRENT ROAD FOR REDUCING TRAFFIC LOAD ACTING ON SUBGRADE
}

\author{
Shinichiro TSUJI, Mikio YAMADA, Masaki YOSHIDA, \\ Kazuhiro MINAMI and Yutaka YASUNAGA
}

\footnotetext{
When the performance of road pavement deteriorates to specified management value due to traffic load, the road pavement is repaired or reconstructed. If the subgrade is softer, it needs the periodic repair for crack and faulting occurring with the settlement of subgrade. In the present study, we developed the "Packed-Foamed Cement Milk" which the lightweight foamed cement milk is injected in the bag made by geotextile. To reduce the traffic road acting on subgrade and to extend the repair cycle of road, we applied the Packed-Foamed Cement Milk to the current road on soft ground. This paper reports the design, evaluation and construction of road pavement by using Packed-Foamed Cement Milk.
} 